\title{
Effects of changes in carbonate chemistry speciation on Coccolithus braarudii: a discussion of coccolithophorid sensitivities
}

\author{
S. A. Krug, K. G. Schulz, and U. Riebesell \\ Leibniz Institute of Marine Sciences (IFM-GEOMAR), Düsternbrooker Weg 20, 24105 Kiel, Germany \\ Received: 1 November 2010 - Published in Biogeosciences Discuss.: 2 December 2010 \\ Revised: 21 March 2011 - Accepted: 22 March 2011 - Published: 24 March 2011
}

\begin{abstract}
Ocean acidification and associated shifts in carbonate chemistry speciation induced by increasing levels of atmospheric carbon dioxide $\left(\mathrm{CO}_{2}\right)$ have the potential to impact marine biota in various ways. The process of biogenic calcification, for instance, is usually shown to be negatively affected. In coccolithophores, an important group of pelagic calcifiers, changes in cellular calcification rates in response to changing ocean carbonate chemistry appear to differ among species. By applying a wider $\mathrm{CO}_{2}$ range we show that a species previously reported insensitive to seawater acidification, Coccolithus braarudii, responds both in terms of calcification and photosynthesis, although at higher levels of $\mathrm{CO}_{2}$. Thus, observed differences between species seem to be related to individual sensitivities while the underlying mechanisms could be the same. On this basis we develop a conceptual model of coccolithophorid calcification and photosynthesis in response to $\mathrm{CO}_{2}$-induced changes in seawater carbonate chemistry speciation.
\end{abstract}

\section{Introduction}

Following the industrial revolution in the late 18th century, atmospheric carbon dioxide levels continuously increased from about 280 to presently $395 \mu \mathrm{atm}$, and are currently increasing further at a rate of $0.4 \%$ per year (IPCC, 2007). The magnitude of this change would have been considerably larger if the surface oceans had not absorbed approximately $50 \%$ of the fossil fuel emissions to date (Sabine et al., 2004). The dissolution of anthropogenic $\mathrm{CO}_{2}$ in water is followed by several chemical reactions leading to shifts in carbonate chemistry speciation resulting in decreasing $\mathrm{pH}$, carbonate ion concentration, and saturation state (ocean acidification) and concomitant increases in the overall dissolved inorganic carbon inventory (ocean carbonation). This conceptual separation is of potential interest for understanding the basis of any physiological response to changes in seawater carbonate chemistry.

Coccolithophores are significant pelagic calcifiers, contributing about half to calcium carbonates preserved in open ocean sediments (Broecker and Clark 2009). They are among the best examined organisms with respect to their response to ocean acidification/carbonation (e.g. Riebesell et al., 2000; Zondervan et al., 2002; Sciandra et al. 2003; Langer et al., 2006, 2009; Feng et al., 2008; Shi et al., 2009; Barcelos e Ramos et al., 2010). Confusingly, the species analyzed so far have different response patterns for calcification and photosynthesis in response to changing carbonate chemistry speciation. While Emiliania huxleyi and Gephyrocapsa oceanica usually decreased calcification rates between a partial pressure of $\mathrm{CO}_{2}\left(p \mathrm{CO}_{2}\right)$ from about 180 to $800 \mu$ atm (Riebesell et al., 2000; Zondervan et al., 2002; Sciandra et al., 2003; Barcelos e Ramos et al., 2010), Calcidiscus quadriperforatus showed an optimum curve response, with a maximum at current $p \mathrm{CO}_{2}$, and Coccolithus braarudii was not significantly changing calcification rates in this range (Langer et al., 2006). Similarly, there were also differences regarding organic carbon fixation rates by photosynthesis, questioning the operation of common cellular mechanisms for calcification and photosynthesis within the group of coccolithophores.

Here we investigate the response of Coccolithus braarudii to a broader $p \mathrm{CO}_{2}$ range in two experiments, allowing to draw conclusions on the origin of observed differences between species. 
Table 1. Carbon chemistry speciation for experiment I and II, calculated as the mean of start and end values of measured DIC and TA. See materials and methods for details. It is noted that the higher variability of DIC concentrations in the second compared to the first experiment is due to inaccuracies in artificial seawater preparation and slightly higher variability in final cell densities.

\begin{tabular}{|c|c|c|c|c|c|c|c|c|c|}
\hline \multicolumn{10}{|c|}{ Experiment I } \\
\hline & $\begin{array}{c}\text { DIC } \\
\mu \mathrm{mol} \mathrm{kg}^{-1}\end{array}$ & $\begin{array}{c}\text { TA } \\
\mu \mathrm{mol} \mathrm{kg}\end{array}$ & $\begin{array}{c}p \mathrm{CO}_{2} \\
\mu \mathrm{atm}\end{array}$ & $\begin{array}{c}{\left[\mathrm{CO}_{2}\right]} \\
\mu \mathrm{mol} \mathrm{kg} \\
-1\end{array}$ & $\begin{array}{c}{\left[\mathrm{HCO}_{3}^{-}\right]} \\
\mu \mathrm{mol} \mathrm{kg}\end{array}$ & $\begin{array}{c}{\left[\mathrm{CO}_{3}^{2-}\right]} \\
\mu \mathrm{mol} \mathrm{kg}^{-1}\end{array}$ & $\Omega_{\text {calcite }}$ & $\mathrm{pH}_{\text {total }}$ & $\begin{array}{c}{\left[\mathrm{H}^{+}\right]} \\
\mathrm{nmol} \mathrm{kg}^{-1}\end{array}$ \\
\hline 1 & 2048 & 2240 & 505 & 17.8 & 1887.9 & 142.3 & 3.4 & 7.96 & 10.96 \\
\hline 2 & 2058 & 2249 & 512 & 18.0 & 1898.0 & 142.0 & 3.4 & 7.96 & 10.96 \\
\hline 3 & 2062 & 2238 & 555 & 19.5 & 1909.9 & 132.6 & 3.2 & 7.92 & 12.02 \\
\hline 4 & 2058 & 2135 & 1015 & 35.7 & 1947.0 & 75.3 & 1.8 & 7.67 & 21.38 \\
\hline 5 & 2022 & 2077 & 1166 & 41.0 & 1917.4 & 63.6 & 1.5 & 7.60 & 25.12 \\
\hline 6 & 2057 & 2103 & 1273 & 44.8 & 1951.8 & 60.4 & 1.4 & 7.57 & 26.92 \\
\hline 7 & 2005 & 2021 & 1566 & 55.1 & 1903.2 & 46.7 & 1.1 & 7.47 & 33.88 \\
\hline 8 & 2048 & 2052 & 1755 & 61.7 & 1942.9 & 43.4 & 1.0 & 7.43 & 37.15 \\
\hline 9 & 2058 & 2041 & 2075 & 73.0 & 1948.1 & 36.9 & 0.9 & 7.36 & 43.65 \\
\hline 10 & 2032 & 2008 & 2170 & 76.3 & 1921.3 & 34.3 & 0.8 & 7.33 & 46.77 \\
\hline 11 & 2065 & 2030 & 2384 & 83.8 & 1949.0 & 32.2 & 0.8 & 7.30 & 50.12 \\
\hline 12 & 2060 & 2025 & 2380 & 83.7 & 1944.2 & 32.0 & 0.8 & 7.30 & 50.12 \\
\hline 13 & 2026 & 1943 & 3311 & 116.5 & 1887.8 & 21.7 & 0.5 & 7.14 & 72.44 \\
\hline 14 & 2035 & 1940 & 3581 & 126.0 & 1888.9 & 20.1 & 0.5 & 7.11 & 77.62 \\
\hline 15 & 2042 & 1945 & 3631 & 127.7 & 1894.4 & 19.9 & 0.5 & 7.10 & 79.43 \\
\hline \multicolumn{10}{|c|}{ Experiment II } \\
\hline & $\begin{array}{c}\text { DIC } \\
\mu \mathrm{mol} \mathrm{kg}^{-1}\end{array}$ & $\begin{array}{c}\text { TA } \\
\mu \mathrm{mol} \mathrm{kg}\end{array}$ & $\begin{array}{l}p \mathrm{CO}_{2} \\
\mu \text { atm }\end{array}$ & $\begin{array}{c}{\left[\mathrm{CO}_{2}\right]} \\
\mu \mathrm{mol} \mathrm{kg} \\
-1\end{array}$ & $\begin{array}{c}{\left[\mathrm{HCO}_{3}^{-}\right]} \\
\mu \mathrm{mol} \mathrm{kg}\end{array}$ & $\begin{array}{c}{\left[\mathrm{CO}_{3}^{2-}\right]} \\
\mu \mathrm{mol} \mathrm{kg}\end{array}$ & $\Omega_{\text {calcite }}$ & $\mathrm{pH}_{\text {total }}$ & $\begin{array}{c}{\left[\mathrm{H}^{+}\right]} \\
\mathrm{nmol} \mathrm{kg}^{-1}\end{array}$ \\
\hline 1 & 2132 & 2385 & 407 & 14.3 & 1932.7 & 185.0 & 4.4 & 8.06 & 8.66 \\
\hline 2 & 2122 & 2370 & 413 & 14.5 & 1926.2 & 181.3 & 4.3 & 8.06 & 8.80 \\
\hline 3 & 2131 & 2375 & 423 & 14.9 & 1937.2 & 178.9 & 4.3 & 8.05 & 8.97 \\
\hline 4 & 2048 & 2230 & 532 & 18.7 & 1893.3 & 136.0 & 3.2 & 7.94 & 11.54 \\
\hline 5 & 2053 & 2235 & 534 & 18.8 & 1898.1 & 136.1 & 3.2 & 7.94 & 11.55 \\
\hline 6 & 2068 & 2243 & 560 & 19.7 & 1916.1 & 132.2 & 3.2 & 7.92 & 12.01 \\
\hline 7 & 2061 & 2162 & 863 & 30.4 & 1942.5 & 88.2 & 2.1 & 7.74 & 18.25 \\
\hline 8 & 2055 & 2149 & 901 & 31.7 & 1939.1 & 84.2 & 2.0 & 7.72 & 19.08 \\
\hline 9 & 2059 & 2152 & 910 & 32.0 & 1943.2 & 83.8 & 2.0 & 7.72 & 19.22 \\
\hline 10 & 1973 & 2028 & 1133 & 39.9 & 1870.8 & 62.3 & 1.5 & 7.60 & 24.87 \\
\hline 11 & 1974 & 2018 & 1235 & 43.4 & 1873.2 & 57.4 & 1.4 & 7.57 & 27.06 \\
\hline 12 & 1976 & 2017 & 1265 & 44.5 & 1875.4 & 56.1 & 1.3 & 7.56 & 27.70 \\
\hline 13 & 2094 & 2108 & 1656 & 58.2 & 1987.6 & 48.1 & 1.1 & 7.47 & 34.21 \\
\hline 14 & 2102 & 2107 & 1781 & 62.6 & 1994.3 & 45.1 & 1.0 & 7.44 & 36.67 \\
\hline 15 & 2080 & 2083 & 1792 & 63.0 & 1973.1 & 43.8 & 1.0 & 7.43 & 37.30 \\
\hline
\end{tabular}

\section{Methods}

The response of Coccolithus braarudii to changing seawater carbonate chemistry was analysed in two experiments. In the first experiment the $p \mathrm{CO}_{2}$ was varied from 500 to $3500 \mu \mathrm{atm}$ and in the second from 400 to $1700 \mu$ atm (compare Table 1).

Monospecific cultures of Coccolithus braarudii (strain RCC 1200, isolated in the South Atlantic off Namibia and kindly provided by the Roscoff Culture Collection http:// www.sb-roscoff.fr/Phyto/RCC/) were incubated in triplicates as dilute batch cultures.
Cells were grown in sterile-filtered natural North Sea water in the first experiment, and, for technical reasons, in artificial seawater (Kester et al., 1967) in the second experiment, both at a temperature of $17^{\circ} \mathrm{C}$ and a salinity of 34 . To ensure exponential growth without nutrient limitation $80 \mu \mathrm{mol} \mathrm{kg}-1$ of nitrate and $5 \mu \mathrm{mol} \mathrm{kg}{ }^{-1}$ of phosphate, trace metals, selenium and vitamins according to the $\mathrm{f} / 2$-medium (Guillard, 1975) were added. The incident photon flux density (PFD) was $130 \mu \mathrm{mol} \mathrm{m}^{-2} \mathrm{~s}^{-1}$ at a $16 / 8$ light/dark cycle. 


\section{Carbonate system manipulation}

Manipulation of carbonate chemistry speciation to simulate ongoing ocean acidification can be achieved by either changing dissolved inorganic carbon (DIC) at constant total alkalinity (TA) or by varying TA at constant DIC (compare Schulz et al., 2009 and Gattuso et al., 2010). The latter approach was chosen here for direct comparability with a previous study on Coccolithus braarudii (Langer et al., 2006). It is noted that there are differences in carbonate chemistry speciation between DIC and TA manipulation. In terms of magnitude and sign in concentration changes they are marginal for $\mathrm{CO}_{2}$ ranges from 180 to $800 \mu \mathrm{atm}$, while towards higher levels there are increasing differences in terms of biocarbonate $\left(\mathrm{HCO}_{3}^{-}\right)$concentration changes which start to decrease when manipulating TA instead of constantly increasing when manipulating DIC (Schulz et al., 2009). However, this was only the case at the highest $p \mathrm{CO}_{2}$ level of about $3500 \mu \mathrm{atm}$ (compare Table 1). There are also increasing differences in $\mathrm{CO}_{3}^{2-}$ ion concentration changes towards such high $p \mathrm{CO}_{2}$ levels, but $\mathrm{CO}_{3}^{2-}$ concentrations steadily decrease in both manipulations.

TA was manipulated by adding suitable amounts of $1 \mathrm{M} \mathrm{HCl}$ or $1 \mathrm{M} \mathrm{NaOH}$ to the $0.2 \mu \mathrm{m}$ filtered seawater. Carbonate chemistry speciation was calculated from measured DIC and TA (see below) adopting the stoichiometric equilibrium constants for carbonic acid determined by Mehrbach et al. (1973) and refitted by Dickson and Millero (1987) as a mean of initial and final values (compare Table 1).

\section{Experimental setup and measurements}

For acclimation, pre-cultures were grown exponentially for 7 days under the experimental conditions before transfer to experimental bottles. All bottles were incubated in triplicates without headspace for 6-17 days, depending on growth rate. To avoid pronounced variations in the carbonate system, maximum cell numbers at the end of incubations did not exceed 2600 in the first and 4500 cells ml $^{-1}$ in the second experiment. This corresponds to a maximum DIC drawdown of less than $12 \%$.

Samples for DIC and TA were taken at the beginning and the end of both the acclimation and experimental phase. Suspended particulate inorganic carbon (PIC), otherwise interfering with the measurements, was removed by gentle pressure filtration $(0.2 \mu \mathrm{m})$ from DIC and by vacuum filtration (GF/F, nominal pore size $0.7 \mu \mathrm{m}$ ) from TA samples. DIC was determined photometrically according to Stoll et al. (2001) with an auto-analyzer (QUAATRO, Bran and Lübbe) at a precision of $\pm 20 \mu \mathrm{mol} \mathrm{kg}-1$. TA was determined by potentiometric titration in duplicate samples at $20^{\circ} \mathrm{C}$ (Metrohm Basic Titrino 794) with 0.05 M HCl (Dickson, 1981; Dickson et al., 2003) at a precision of $\pm 3 \mu \mathrm{mol} \mathrm{kg}{ }^{-1}$. Certified reference material (University of California, San Diego, Marine Physical Laboratory, A. G. Dickson) was measured alongside with the samples as an independent standard and used for corrections.

Samples for cell abundance were determined with a $\mathrm{Z} 2^{\mathrm{TM}}$ COULTER COUNTER ${ }^{\circledR}$ cell and particle counter in the first and, for technical reasons, by light microscopy in the second experiment.

The cell abundances at the start $\left(c_{0}\right)$ and at the end of incubations $\left(c_{1}\right)$ were used to calculate daily growth rates $(\mu)$ during the experimental incubation period $(\Delta t$, incubation time in days) as:

$\mu=\frac{\ln c_{1}-\ln c_{0}}{\Delta t}$

The initial cell abundance was based on cell counts of the inoculum. Independent incubations with daily cell counts did not reveal a significant lag phase for the approach applied here. Initial and final cell abundances can therefore be used to calculate mean daily growth rate.

At the end of the experiment duplicate samples for total particulate carbon (TPC) and nitrogen (TPN) and particulate organic carbon (POC) and nitrogen (PON) were filtered onto pre-combusted $\left(450^{\circ} \mathrm{C}\right.$ for $8 \mathrm{~h}$ ) $\mathrm{GF} / \mathrm{F}$ (Whatman) filters and frozen at $-20^{\circ} \mathrm{C}$ until analysis. For POC determination, particulate inorganic carbon was removed by exposing the filters to fuming hydrochloric acid for 12 hours. Before measurement all filters were dried at $60^{\circ} \mathrm{C}$. Afterwards they were folded and packed in tin cups and analysed in an elemental analyser with a heat conductivity detector (EuroVector EA) according to Sharp (1974).

\section{Results}

Manipulation of TA by about $300 \mu \mathrm{mol} \mathrm{kg}{ }^{-1}$ at constant DIC created a $p \mathrm{CO}_{2}$ gradient from about 500 to $3500 \mu \mathrm{atm}$ in the first experiment and from about 400 to $1700 \mu$ atm in the second experiment. Considering the combined $p \mathrm{CO}_{2}$ range $\left[\mathrm{CO}_{2}\right],\left[\mathrm{CO}_{3}^{2-}\right]$ and $\left[\mathrm{H}^{+}\right]$changed relatively proportional by a factor of about 9 . While $\left[\mathrm{CO}_{2}\right]$ was rising from 14 to $124 \mu \mathrm{mol} \mathrm{kg}{ }^{-1}$ and $\left[\mathrm{H}^{+}\right]$from 6.9 to $63 \mathrm{nmol} \mathrm{kg}^{-1},\left[\mathrm{CO}_{3}^{2-}\right]$ dropped from 181 to $21 \mu \mathrm{mol} \mathrm{kg}{ }^{-1}$. [ $\left[\mathrm{HCO}_{3}^{-}\right]$was much less affected within the same range and varied by a factor less than 1.06 between treatments (compare Table 1). Two out of ten triplicate treatments were clearly under-saturated with respect to calcite $\left(\Omega_{\text {calcite }}<1\right)$ while another two were only slightly above one.

POC production rates of Coccolithus braarudii were highest at intermediate $p \mathrm{CO}_{2}\left(300 \mathrm{pgCcell}^{-1} \mathrm{~d}^{-1}\right)$ and declined towards lower and higher levels (200 and less than $100 \mathrm{pgC} \mathrm{Cell}^{-1} \mathrm{~d}^{-1}$, respectively), although more pronounced in case of the latter (Fig. 1a). Calcification rates, although quite noisy, clearly decreased towards higher $p \mathrm{CO}_{2}$ levels from about $300-400 \mathrm{p} \mathrm{C}$ cell $^{-1} \mathrm{~d}^{-1}$ at the lower end to less than $25 \mathrm{pgC} \mathrm{Cell}^{-1} \mathrm{~d}^{-1}$ at the higher end of the $p \mathrm{CO}_{2}$ range (Fig. 1b). The considerably stronger decrease in PIC 

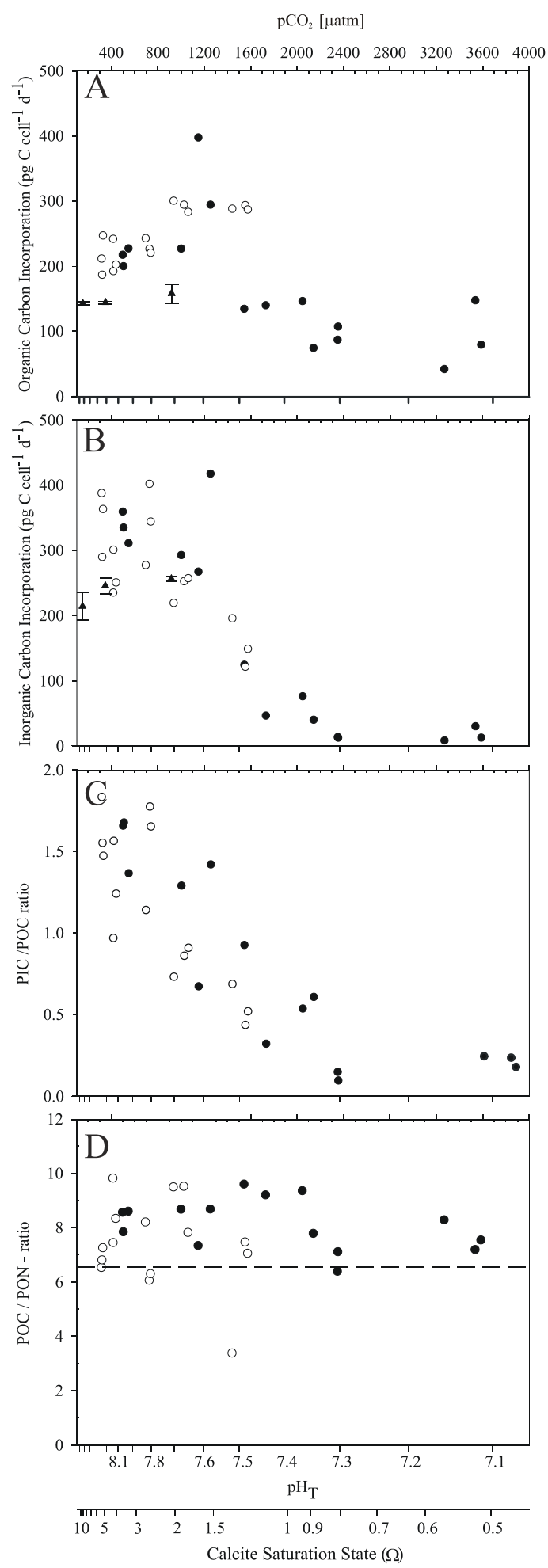

Fig. 1. Particulate organic and inorganic carbon production rates - (A) and (B), respectively - together with ratios of particulate inorganic to organic carbon $(\mathbf{C})$ and particulate organic carbon to nitrogen (D) in response to changes in carbon chemistry speciation. Filled circles represent results of the first and open circles of the second experiment, while triangles those of Langer et al. (2006) for comparison.
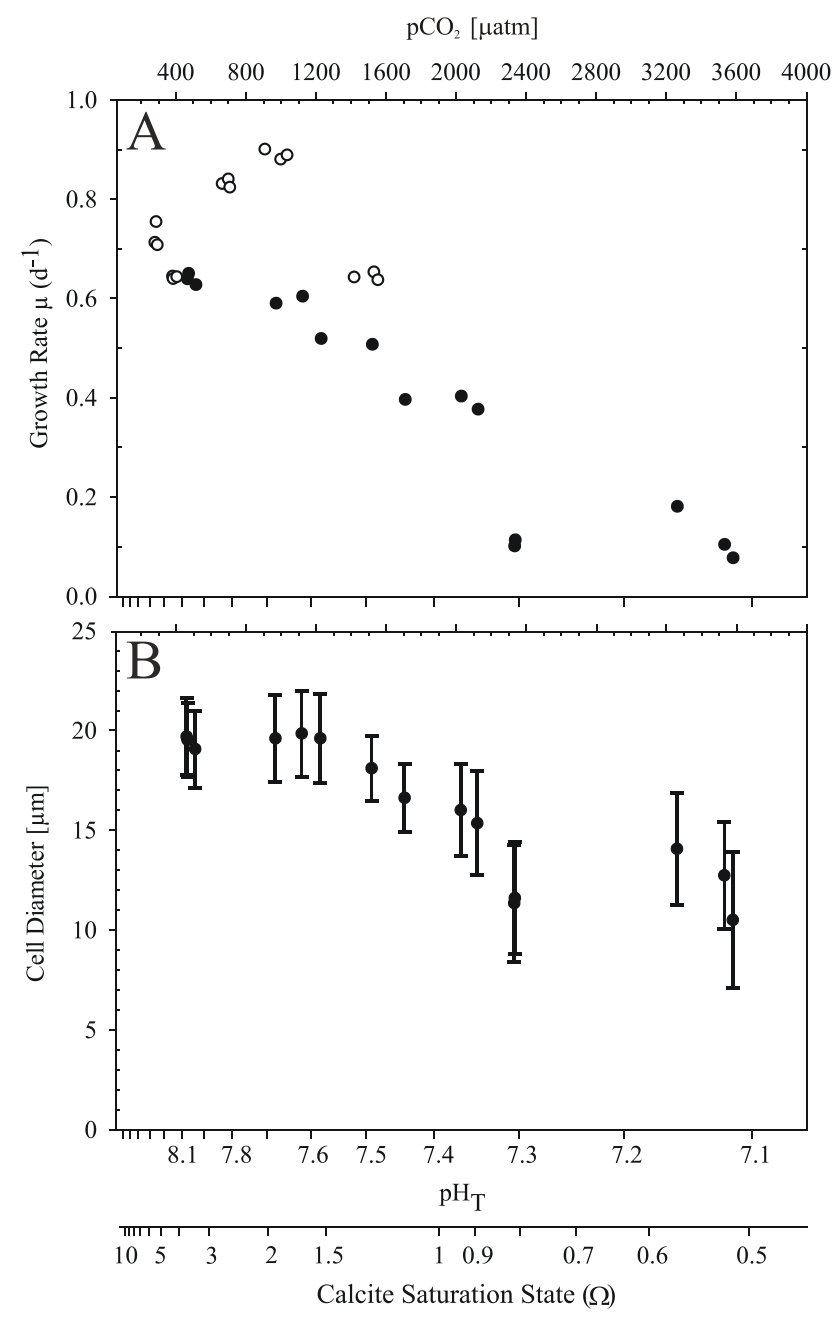

Fig. 2. Growth rates $(\mu)$ of Coccolithus braarudii in the first (filled circles) and second experiment (open circles) and together with cell diameter as measured in the first experiment in response to changing carbon chemistry speciation - (A) and (B), respectively.

compared to POC production led to a pronounced drop in PIC/POC (Fig. 1c). The variations in POC production, however, were not reflected in POC/PON, which generally fluctuated slightly above the Redfield ratio of 6.6 in all treatments (Fig. 1d).

Growth rates ranged between 0.6 and $0.9 \mathrm{~d}^{-1}$ at lower $p \mathrm{CO}_{2}$ and decreased to less than $0.2 \mathrm{~d}^{-1}$ towards the higher levels (Fig. 2a), while cell diameter decreased almost by a factor of two (Fig. 2b).

\section{Discussion}

The response of coccolithophorid calcification and photosynthetic carbon fixation rates to changing carbonate chemistry speciation, more specifically to a $p \mathrm{CO}_{2}$ range from about 180 to $800 \mu \mathrm{atm}$, has been shown to differ between species, 
challenging the concept of common cellular mechanisms for these two processes in coccolithophores. While calcification rates were found to decrease with increasing $p \mathrm{CO}_{2}$ in Emiliania huxleyi and Gephyrocapsa oceanica (Riebesell et al., 2000; Zondervan et al., 2002; Sciandra et al., 2003; Barcelos e Ramos et al., 2010), Calcidiscus quadriperforatus showed an optimum curve response, and Coccolithus braarudii no sign of change (Langer et al., 2006). Similarly, photosynthetic carbon fixation rates were found to increase in Emiliania huxleyi and Gephyrocapsa oceanica, while not being significantly affected in Calcidiscus quadriperforatus and Coccolithus braarudii. Extending the $p \mathrm{CO}_{2}$ range towards higher values, however, revealed that the processes of calcification and photosynthesis in Coccolithus braarudii are indeed prone to changes in carbonate chemistry speciation (Fig. 1a and b). Calcification rates clearly decreased with increasing $p \mathrm{CO}_{2}$ as observed in Emiliania huxleyi and Gephyrocapsa oceanica, although at higher levels of $p \mathrm{CO}_{2}$. They were lowest at the two highest $\mathrm{CO}_{2}$ levels when calcite saturation was below one. Here calcite dissolution may have occurred and contributed to the low rates of net calcification. Photosynthetic carbon fixation rates were highest at intermediate $p \mathrm{CO}_{2}$, suggesting an optimum curve response like seen for calcification in Calcidiscus quadriperforatus. When extending the $p \mathrm{CO}_{2}$ range towards lower levels calcification and photosynthetic carbon fixation rates have been shown to decrease with decreasing $p \mathrm{CO}_{2}$ in Emiliania huxleyi, although seemingly stronger in case of the latter (Buitenhuis et al., 1999).

A conceptual model of carbonate chemistry dependant photosynthesis and calcification in coccolithophores

Putting all pieces of information together we propose that changes in calcification and photosynthetic carbon fixation rates in response to changing carbonate chemistry are likely to have the same underlying mechanisms in all coccolithophores, with both processes characterized by an optimum curve response (compare Fig. 3). The observed species specific differences would reflect species specific carbonate chemistry sensitivities rather than different cellular mechanisms. This concept could also explain strain-specific differences observed for Emiliania huxleyi (Langer et al., 2009).

Identifying the carbonate chemistry parameters responsible for calcification and photosynthetic carbon fixation rate changes towards both ends of the optima of the proposed model is difficult. While towards the lower end concentrations of $\mathrm{CO}_{2}, \mathrm{HCO}_{3}^{-}$and $\mathrm{H}^{+}$are decreasing and $\mathrm{pH}, \mathrm{CO}_{3}^{2-}$ concentration and calcite saturation state $\left(\Omega_{\text {calc }}\right)$ are increasing, these trends are reversed towards the higher end (compare Fig. 3). This poses the question for the optimum conditions in terms of carbonate chemistry speciation for calcification and photosynthesis.

Maximizing any biological rate requires the availability of saturating substrate concentrations and optimal

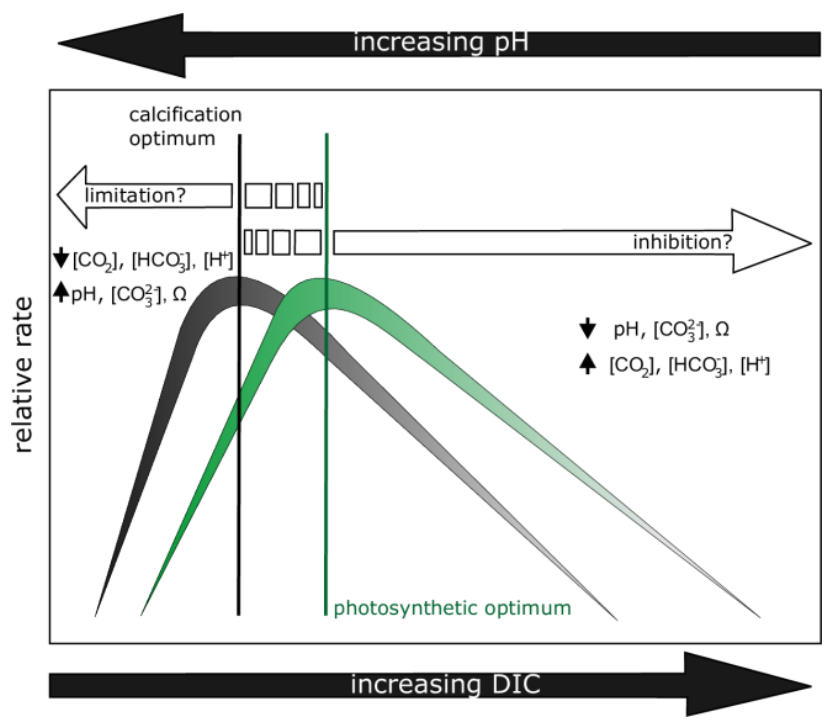

Fig. 3. Conceptual model of coccolithophorid photosynthesis and calcification in response to changes in carbonate chemistry speciation due to increasing DIC at decreasing $\mathrm{pH}$.

ambient conditions. During photosynthetic carbon fixation $\mathrm{CO}_{2}$ is fixed by the enzyme Ribulose-1,5-BisphosphatCarboxylase/Oxygenase (RuBisCO) in the chloroplast, while calcification is sustained by inorganic precipitation of $\mathrm{Ca}^{2+}$ and $\mathrm{CO}_{3}^{2-}$ ions forming calcite in the coccolith producing vesicle. Emiliania huxleyi, like probably most phytoplankton species, is known to fuel photosynthesis by active uptake of both $\mathrm{CO}_{2}$ and $\mathrm{HCO}_{3}^{-}$from the surrounding seawater (Rost et al., 2003; Schulz et al., 2007), however simultaneous $\mathrm{CO}_{3}^{2-}$ ion uptake by $\mathrm{HCO}_{3}^{-}$transporters can not be ruled out (Mackinder et al., 2010). Although there is uncertainty about the actual substrate taken up for calcification, it is difficult to conceive how cells would be able to operate an internal carbon pool for calcification separated from that used in photosynthesis. This means that there should be thresholds for the concentrations of at least two of the dissolved inorganic carbon species in seawater $\left(\mathrm{CO}_{2}, \mathrm{HCO}_{3}^{-}\right)$below which uptake and ultimately supply to photosynthesis and calcification becomes sub-saturating. Furthermore, the concentration of $\mathrm{CO}_{2}$ in seawater influences the operation of carbon concentrating mechanisms (CCMs) in marine phytoplankton. Decreasing concentrations can be thought to increase the gradient between seawater and cytosol, resulting in enhanced net diffusive loss of $\mathrm{CO}_{2}$ out of the cytosol, and, if not compensated for, decreasing internal $\mathrm{CO}_{2}$ concentrations (compare Schulz et al., 2007). This implies that if cytosolic $\mathrm{pH}$ is not increasing simultaneously there would be less dissolved inorganic carbon ultimately available as substrate, eventually resulting in reduced rates of photosynthesis and calcification. The enhanced leakiness at low seawater $\mathrm{CO}_{2}$ concentrations can also be expected to increase metabolic costs of carbon supply to photosynthesis and calcification. 
Concerning optimal conditions for these two processes cellular $\mathrm{pH}$, or $\mathrm{H}^{+}$concentration, is an important factor. Photosynthetic carbon fixation is mediated by a $\mathrm{pH}$ dependent enzymatic reaction (Portis et al., 1986). Decreasing seawater $\mathrm{pH}$ has been shown to result in lower intracellular $\mathrm{pH}$ levels in Emiliania huxleyi (Suffrian et al., 2011). Whether this is directly affecting rates of photosynthetic carbon fixation and inorganic carbon precipitation or whether reduced rates are connected to an overall reduced cell metabolism, is not known. Indeed, changes in the intracellular $\mathrm{pH}$ reported by Suffrian et al. (2011) can be perceived as a mixed signal of all compartments. It is therefore unknown whether a change in cytosolic $\mathrm{pH}$ also affect $\mathrm{pH}$ in the coccolith vesicle and/or chloroplast. However, even in case of unaffected $\mathrm{pH}$ in both vesicl, the energetic costs of calcification and photosynthesis may still be affected as the costs of proton transport across the vesicle and cell membrane will depend on proton gradients. Variations in seawater $\mathrm{pH}$ therefore have the potential to directly impact rates of photosynthesis and calcification. The observed changes could also be related to down-regulation of RubisCO gene expression and increasing regeneration time of the coccolith vesicle after a completed coccolith is channelled out of the cell.

In the proposed model, changes in carbonate chemistry speciation such as increasing DIC at decreasing $\mathrm{pH}$ could be thought to enhance calcification and photosynthesis by supplying increasing amounts of substrate up to a certain threshold beyond which $\mathrm{pH}$ levels become unfavourable (compare Fig. 3). Ocean carbonation (increasing concentrations of $\mathrm{CO}_{2}$ and $\mathrm{HCO}_{3}^{-}$) and acidification (decreasing $\mathrm{pH}$ ) could therefore act differently on these two processes. However, at this point contributions of $\mathrm{pH}$ to the shape of the optimum curve on the left side of the optimum and of $\mathrm{CO}_{2}$ on the right side cannot be ruled out either. In any case, both photosynthesis and calcification are likely to have optimum concentrations for at least $\mathrm{CO}_{2}, \mathrm{HCO}_{3}^{-}$and $\mathrm{H}^{+}$. Observed species- and strain-specific differences in coccolithophorid photosynthesis and calcification to changes in carbonate chemistry could then be the result of different optimum concentrations for these ions. In other words, different sensitivities rather than divergent intra-cellular mechanisms for photosynthesis and calcification between species and maybe even strains may explain the different responses reported for Emiliania huxleyi, Gephyrocapsa oceanica, Calcidiscus leptoporus and Coccolithus braarudii.

Acknowledgements. We thank our working group for inspiring discussions, Michael Meyerhöfer for DIC measurements, and Ian Probert for kindly supplying the Coccolithus braarudii strain. We would also like to thank the EPOCA project, funded by the European Commission and the German program on Biological Impacts of Ocean Acidification (BIOACID) for the financial support.

Edited by: W. Kiessling

\section{References}

Barcelos e Ramos, J., Müller, M. N., and Riebesell, U.: Shortterm response of the coccolithophore Emiliania huxleyi to an abrupt change in seawater carbon dioxide concentrations, Biogeosciences, 7, 177-186, doi:10.5194/bg-7-177-2010, 2010.

Broecker, W. and Clark, E.: Ratio of coccolith $\mathrm{CaCO}_{3}$ to foraminifera $\mathrm{CaCO}_{3}$ in late Holocene deep sea sediments, Paleoceanography, 24, PA3205, doi:10.1029/2009PA001731, 2009.

Buitenhuis, E. T., de Baar, H. J. W., and Veldhuis, M. J. W.: Photosynthesis and calcification by Emiliania huxleyi (Prymnesiophyceae) as a function of inorganic carbon species, J. Phycol., 35, 949-959, 1999.

Dickson, A. G.: An exact definition of total alkalinity and a procedure for the estimation of alkalinity and total inorganic carbon from titration data, Deep-Sea Res., 28, 609-623, 1981.

Dickson, A. G. and Millero, F. J.: A comparison of the equilibrium constants for the dissociation of carbonic acid in seawater media, Deep-Sea Res., 34, 1733-1731, 1987.

Dickson, A. G., Afghan, J. D., and Anderson, G. C.: Reference materials for oceanic $\mathrm{CO}_{2}$ analysis: a method for the certification of total alkalinity, Mar. Chem., 80, 185-197, 2003.

Feng, Y., Warner, M. E., Zhang, Y., Sun, J., Fu, F. X., Rose, J. M., and Hutchins, D. A.: Interactive effects of increased $p \mathrm{CO}_{2}$, temperature and irradiance on the marine coccolithophore Emiliania huxleyi (Prymnesiophyceae), Eur. J. Phycol., 43, 87-98, 2008.

Gattuso, J. P., Gao, K. S., Lee, K., Rost, B., and Schulz, K. G.: Approaches and tools to manipulate the carbonate chemistry, in: Guide to best practices for ocean acidification research and data reporting, edited by: Riebesell, U., Fabry, V. J., Hansson, L., and Gattuso, J. P., Publications Office of the European Union, Luxembourg, 41-52, 2010.

Guillard, R.: Culture of phytoplankton for feeding marine invertebrates, in: Culture of marine invertebrates, edited by: Smith, W. and Chanley, M., Plenum, 29-60, 1975.

IPCC: Working Group I Fourth Assessment Report "The Physical Science Basis", Cambridge University Press, 2007.

Kester, D. R., Duedall, I. W., Conners, D. N., and Pytkowicz, R. M.: Preparation of artificial seawater, Limnol. Oceanogr., 12, 176179, 1967.

Langer, G., Geisen, M., Baumann, K. H., Klas, J., Riebesell, U., Thoms, S., and Young, J. R.: Species-specific responses of calcifying algae to changing seawater carbonate chemistry, Geochem. Geophy. Geosy., 7, Q09006, doi:10.1029/2005GC001227, 2006.

Langer, G., Nehrke, G., Probert, I., Ly, J., and Ziveri, P.: Strain-specific responses of Emiliania huxleyi to changing seawater carbonate chemistry, Biogeosciences, 6, 2637-2646, doi:10.5194/bg-6-2637-2009, 2009.

Mackinder, L., Wheeler, G., Schroeder, D., Riebesell, U., and Brownlee, C.: Molecular Mechanisms Underlying Calcification in Coccolithophores, Geomicrobiol. J., 27, 585-595, 2010.

Mehrbach, C., Culberson, C. H., Hawley, J. E., and Pytkowicz, R. M.: Measurement of the apparent dissociation constants of carbonic acid in seawater at atmospheric pressure, Limnol. Oceanogr., 18, 897-907, 1973.

Portis, A. R., Salvucci, M. E., and Ogren, W. L.: Activation of Ribulosebisphosphate Carboxylase/Oxygenase at Physiological $\mathrm{CO}_{2}$ and Ribulosebisphosphate Concentrations by Rubisco Activase, Plant Physiol., 82, 967-971, 1986. 
Riebesell, U., Zondervan, I., Rost, B., Tortell, P. D., Zeebe, R. E., and Morel, F. M. M.: Reduced calcification of marine plankton in response to increased atmospheric $\mathrm{CO}_{2}$, Nature, 407, 364-367, 2000.

Rost, B., Riebesell, U., Burkhardt, S., and Sultemeyer, D.: Carbon acquisition of bloom-forming marine phytoplankton, Limnol. Oceanogr., 48, 55-67, 2003.

Sabine, C. L., Feely, R. A., Gruber, N., Key, R. M., Lee, K., Bullister, J. L., Wanninkhof, R., Wong, C. S., Wallace, D. W. R., Tilbrook, B., Millero, F. J., Peng, T. H., Kozyr, A., Ono, T., and Rios, A. F.: The oceanic sink for anthropogenic $\mathrm{CO}_{2}$, Science, 305, 367-371, 2004.

Schulz, K. G., Rost, B., Burkhardt, S., Riebesell, U., Thoms, S., and Wolf-Gladrow, D. A.: The effect of iron availability on the regulation of inorganic carbon acquisition in the coccolithophore Emiliania huxleyi and the significance of cellular compartmentation for stable carbon isotope fractionation, Geochim. Cosmochim. Acta, 71, 5301-5312, 2007.

Schulz, K. G., Barcelos e Ramos, J., Zeebe, R. E., and Riebesell, $\mathrm{U}$.: $\mathrm{CO}_{2}$ perturbation experiments: similarities and differences between dissolved inorganic carbon and total alkalinity manipulations, Biogeosciences, 6, 2145-2153, doi:10.5194/bg-6-21452009, 2009.
Sciandra, A., Harlay, J., Lefevre, D., Lemee, R., Rimmelin, P., Denis, M., and Gattuso, J. P.: Response of coccolithophorid Emiliania huxleyi to elevated partial pressure of $\mathrm{CO}_{2}$ under nitrogen limitation, Mar. Ecol.-Prog. Ser., 261, 111-122, 2003.

Sharp, J. H.: Improved Analysis for Particulate Organic Carbon and Nitrogen from Seawater, Limnol. Oceanogr., 19, 984-989, 1974.

Shi, D., Xu, Y., and Morel, F. M. M.: Effects of the $\mathrm{pH} / p \mathrm{CO}_{2}$ control method on medium chemistry and phytoplankton growth, Biogeosciences, 6, 1199-1207, doi:10.5194/bg-6-1199-2009, 2009.

Stoll, M. H. C., Bakker, K., Nobbe, G. H., and Haese, R. R.: Continuous-flow analysis of dissolved inorganic carbon content in seawater, Anal. Chem., 73, 4111-4116, 2001.

Suffrian, K., Schulz, K. G., Gutowska, M., Riebesell, U., and Bleich, M.: Cellular pH measurements in Emiliania huxleyi reveal pronounced membrane proton permeability, New Phytol., doi:10.1111/j.1469-8137.2010.03633.x, in press, 2011.

Zondervan, I., Rost, B., and Riebesell, U.: Effect of $\mathrm{CO}_{2}$ concentration on the PIC/POC ratio in the coccolithophore Emiliania huxleyi grown under light-limiting conditions and different daylengths, J. Exp. Mar. Biol. Ecol., 272, 55-70, 2002. 